REMLATE DIE MLALES

Campinas-SP, v.38, n.2, pp. 581-619, jul./dez. 2018

\title{
COSTURA \& SUTURA: TRADUZIR E EDITAR OS FASCÍCULOS DE EMILY DICKINSON
}

\author{
Adalberto Müller ${ }^{1}$
}

\begin{abstract}
Resumo: Desde a sua publicação inicial, os manuscritos de Emily Dickinson foram submetidos a alterações, distorções e apagamentos, bem como a muita tentativa frustrada ou não tão bem-sucedida de preservar a sua singularidade no processo de edição. Em nossos dias, mais de uma edição diferente de suas obras circula em livrarias. Para o tradutor, essa instabilidade coloca o problema de definir qual dos originais que ele irá traduzir. Por isso, propomos aqui uma metodologia de tradução que consiste em duas atitudes: costura e sutura. Na costura, o tradutor desempenha um papel ativo nas escolhas editoriais de modo a criar uma estabilidade e constituir uma versão (tradução) de leitura. Numa outra mão, o processo de sutura aceita a instabilidade da obra (elipses, variantes, alternativas, apagamentos, discórdias interpretativas etc.) e incita a busca incessante de um sujeito (ou sentido) que apenas bruxuleia na cadeia discursiva e é, em sua própria natureza, inatingível. Além disso, se o processo de costura leva em consideração o contexto e o cotexto de um poema para (re)construir o sentido do conteúdo manifesto da obra, a sutura opera no nível do conteúdo latente, considerando que as elipses, variantes, alternativas, supressões etc. criam um regime de indeterminação com o qual o tradutor deve saber lidar. Por isso, a tarefa do tradutor pressupõe imposições estéticas e éticas ao mesmo tempo, pois suas escolhas são feitas antes mesmo da transferência do original para a sua própria língua. Para ilustrar isso tudo, apresentamos aqui em anexo a tradução do fascículo 34 de Emily Dickinson (1863), de acordo com a edição de Cristanne Miller em Emily Dickinson's Poems: As She Preserved Them. (Inclui tradução do fascículo 34).
\end{abstract}

Palavras-chave: tradução; sutura; Emily Dickinson.

"Translation is the most intimate act of reading.

I surrender to the text when I translate."

(Gayatri Chakravorty Spivak)

1 Professor da Universidade Federal Fluminense, Departamento de Ciências da Linguagem: <adalbertomuller@gmail.com>. 


\section{INTRODUÇÃO}

Como se pode pensar, na tradução de uma obra poética, a relação entre a tradução e o original, se o original ainda é marcado por uma instabilidade, se o original não se fixou ainda em um texto definitivo? No caso da obra de Emily Dickinson (1830-1886, doravante ED), a relação entre o original e a sua "origem" está sujeita a uma extensa discussão crítica, uma vez que sua obra ainda é objeto de debates em torno do estabelecimento do texto definitivo. Desse modo, queremos defender que a tarefa do tradutor é dupla: costura e sutura.

Por um lado, ele deve participar do processo de estabelecimento de um texto original, tornando-se também um editor, além de um crítico e de um intérprete (um leitor, em sentido lato). A esse processo damos o nome de costura, pensando no modo como ED costurava seus manuscritos, mas também pensando em muitos poemas dela sobre o tema da costura e do bordado. O papel da costura é o de manter uma coerência textual - na relação entre a obra e a tradução - a partir do confronto com a movência interna da obra, que se evidencia em suas metamorfoses editoriais e interpretativas. No processo de costura, a tradução opera sobre o conteúdo manifesto do texto, sem pensar nas lacunas, nas alternativas, nas variantes, nas rasuras e nos recalques. A costura visa manter estável a coerência da obra, permitindo que ela não se desfaça em meio à multiplicidade de leituras, ou não se transforme numa projeção das escolhas subjetivas do leitor e/ou do tradutor. ${ }^{2}$

Por outro lado, o tradutor deve estar atento para aquilo que não se fecha no próprio texto (elipses, variantes, alternativas, rasuras), para a relação interna dos poemas dentro dos seus "conjuntos" (fascículos, maços, folhas etc.) e, ainda, desses conjuntos dentro de um contexto (histórico e/ ou biográfico). Ou seja, deve ler (e traduzir) aquilo que permanece latente no texto, como potência. A isso damos o nome de sutura, inspirados na teoria da montagem cinematográfica (OUDART, 1977), que, por sua vez, se inspira na psicanálise lacaniana (MILLER, 1966). Consequentemente, operando sobre textos em que a significação é instável em função de sua

2 Um caso interessante de falta de atenção à costura de uma obra é a interpretação de Heidegger aos poemas de Hölderlin, baseadas, segundo Paul de Man, na escolha de uma edição problemática. Mas Heidegger também sutura a edição dos poemas, modificandoos no interesse da sua exegese e de seu programa filosófico. Cf. Paul de Man (1983), pp. 246-266. 
própria materialidade, o processo de sutura permite que a tradução se transforme em diálogo com a alteridade radical que se enuncia nos textos, em suas variantes e alternativas. A sutura visa manter, no texto, o seu caráter de instabilidade (tanto semântica quanto material).

Em conjunto, costura e sutura fazem da tradução um modo ético de posicionar-se diante da alteridade do texto de origem, apontando para a tradução como uma prática e uma ética dialógica (CARDOZO, 2007). Evidentemente, em se tratando de poesia, o aspecto ético não pode prescindir da reflexão e da criação estéticas. De modo que nossa tradução não quer ser apenas recriação ou transcriação, mas também um trabalho crítico e editorial. Esse trabalho, porém, não se confunde com o processo seletivo das antologias, em que se escolhe o que interessa (as flores) e se descarta o que não interessa (a planta e sua raiz). Se quisermos permanecer no vegetal, entenderemos que a posição ética aqui é a de não cortar a flor para dá-la ao leitor, mas levar o leitor até o campo, e percorrer com ele o caminho que leva à compreensão da flor, da folha, do espinho, do caule, da raiz, da terra, do clima, ou seja, da natureza - e sobretudo da natureza como história.

Esse trabalho ao mesmo tempo editorial e tradutório da sutura lembra justamente aquilo que se enuncia no final do texto "Die Aufgabe des Übersetzers" de Walter Benjamin, que cito, aqui, et pour cause, através da citação que Jacques Derrida (1987) faz da tradução de Maurice de Gandillac, inserindo, ao modo de contra-assinatura, algumas palavras do original. Eis, portanto, a citação de uma citação:

\begin{abstract}
Car à un degré quelconque, toutes les grandes écritures [alle die grossen Schriften], mais au plus haut point l'Écriture sainte [die heiligen], contiennent [enthalten] entre les lignes [zwischen den Zeilen] leur traduction virtuelle. La version intralinéaire [Interlinearversion] du texte sacré est le modèle ou l'idéal [Urbild oder Ideal] de toute traduction. (BENJAMIN apud DERRIDA, 1987, p. 235)
\end{abstract}

A sutura ocorre justamente nisso que se passa entre as linhas do texto original, encontrando-se com a tradução que já está lá, enquanto tradução virtual. ${ }^{3}$ Ao contrário da costura, que emenda fragmentos mortos, dando a eles uma legibilidade (como em um Frankenstein), a sutura lida com a vida do texto, com aquilo que nele está ainda vivo e que quer sobreviver,

3 Lembro-me que Berthold Zilly, inspirado no conceito de leitor implícito, propôs a ideia de "tradutor implícito" em Os sertões, no curso sobre a tradução das obras de Euclides da Cunha, em 1997, na FFLCH-USP. 
perviver, ou melhor: transviver. Como aponta Derrida (1987, p. 219), o überleben [sobreviver] benjaminiano tem o mesmo sufixo de übersetzen [traduzir]. O corpo suturado não vive apenas, transvive. Em outros termos, toda sutura deixa uma marca, uma assinatura, ou uma assignatura (DERRIDA, 1988). Essa marca, essa assinatura, é também uma cicatriz, que se pode abrir de novo. Em função disso, o tradutor que sutura mantém-se a caminho da pura língua (reine Sprache) - da pura experiência com a linguagem, do puro deslize do significante - mantém-se nas entrelinhas do original, o que quer dizer que atinge o ponto em que é possível viver com o (dentro do) original, e não apenas ser um intermediário, ou um mensageiro. A sutura transforma a tradução na imagem originária [Urbild] do texto original [Urtext]. Talvez, por isso, a tradução ideal devesse viver com o original. Estar na estante do original. Entre as edições críticas e as interpretações. Pois o lugar da tradução é o entre.

O processo de costura e sutura deverá culminar na primeira edição em livro dos 40 fascículos de Emily Dickinson e sua tradução, seguindo os passos da recente edição da poesia de Dickinson (2016) estabelecida por Cristanne Miller. Apresentamos aqui um desses fascículos como anexo.

\section{COSTURA}

\section{Breve história das edições de Emily Dickinson}

Dos cerca de 1800 poemas que Emily Dickinson escreveu, apenas dez foram publicados quando a poeta ainda estava viva, e quase todos de forma anônima, ou sem sua autorização, em jornais e revistas de circulação regional. A primeira publicação em livro de seus poemas reunidos ocorreu postumamente, em 1891, em volume organizado por T.W. Higginson, amigo e correspondente da poeta, e Mabel Loomis Todd, amante de seu irmão Austin. Essa edição, que circulou até meados dos anos 1920 - e à qual, provavelmente, Manuel Bandeira, seu primeiro tradutor, teve acesso - continha cerca de duzentos poemas apenas. Além da escolha contestável, os poemas foram submetidos a uma brutal descaracterização contextual, gráfica e formal, com a supressão dos famosos "dashes" [travessões] e a eliminação do uso peculiar das maiúsculas, além do acréscimo de uma pontuação que "clarificasse" a sua estranheza gramatical e sintática. Ademais, foram acrescidos títulos aos poemas. Ao longo dos anos 1920 e 1950, novas edições e novos poemas vão sendo publicados, quase sempre sem o cuidado crítico-textual, até que Thomas H. Johnson estabelece, 
em 1951, a primeira edição crítica (edição variorum, em 3 volumes) dos poemas completos.

A edição de Johnson surpreende não apenas pela quantidade de poemas (1.775), mas por incluir, pela primeira vez, as variantes e as alternativas. As variantes são versões diferentes dos poemas, que ED fazia circular através de cartas, ou simplesmente refazendo-os tempos mais tarde. As alternativas consistiam de pequenas modificações ou acréscimos que ED fazia nas margens dos manuscritos, geralmente marcados com um sinal de “+”. Em alguns casos, as variantes modificavam totalmente o sentido dos poemas originais e, em outros, as alternativas abriam possibilidades infinitas de leitura (o leitor verá as alternativas no anexo deste trabalho, à direita da página). O trabalho fundamental de Johnson se completaria com a publicação na íntegra das cartas da poeta, em 1958.

Em 1981, o arquivista e estudioso da poeta, Ralph W. Franklin, publica um livro que mudaria a história da leitura de Emily Dickinson: The Manuscript Books of Emily Dickinson. Seguindo o fio da história textual, dos depoimentos de parentes de ED e da materialidade dos manuscritos, Franklin reconstruiu o que se convencionou chamar de fascículos: conjuntos de uma ou duas dezenas de poemas escritos em folhas de tamanho carta (stationery), já dobradas em quatro faces, perfuradas lateralmente e costuradas em conjuntos de seis a oito folhas, formando um fascículo. A rigorosa reconstrução de Franklin devolveu ao seu estado primitivo os 40 fascículos originais, tal como foram organizados e costurados pela própria ED, entre 1858 e 1864, justamente na época mais prolífica de sua produção - que é, para alguns, a época em que suas ambições literárias ainda estavam bastante nítidas.

A edição em fascículos mostrava que os poemas de ED, em todas as edições anteriores - e mesmo na de Johnson - haviam sido submetidos a escolhas e arranjos arbitrários, muitas vezes rasgando e retirando folhas de um fascículo para reordená-las em outra parte. Se quisermos comparar a obra de ED a um arbusto, digamos que ele foi cortado em muitos fragmentos, que foram arbitrariamente replantados em locais distantes e distintos. A palavra fascículo, aliás, tem origem vegetal. Em botânica, um fascículo ocorre quando há várias flores ou inflorescências que surgem de um ponto apenas (ou nó) do caule. Emily Dickinson tinha um particular interesse pela botânica, desde os anos da juventude, quando organizou um impressionante herbarium. 
A edição dos fascículos passou a levantar algumas questões que ainda hoje permanecem sem resposta: ainda que não tivesse publicado seus poemas, teria ED “pré-editado" os mesmos? E, se o fez, seria essa "edição" uma indicação de como deveriam ser publicados algum dia? Apesar do meticuloso trabalho de arquivista, R. W. Franklin argumenta que a organização em fascículos servia apenas para "ordenar", mas não eram propriamente um trabalho "editorial”. Franklin dizia isso já na edição de 1981 e, sobretudo, na última (1996) edição crítica dos poemas de ED (variorum, 3 volumes, 1.789 poemas). Apesar de sua ressalva, os fascículos passaram a atrair a atenção da crítica e seu caráter "pré-editorial" seria confirmado por Sharon Cameron (1992). Alguns anos depois, Ellen Louise Hart e Martha Nell Smith (1998) demonstram que a edição das cartas levada a cabo por Johnson deixou de lado as "cartas íntimas" de ED a sua ex-amiga de juventude e cunhada Susan Gilbert Dickinson, além de demonstrarem que a fronteira entre as cartas e os poemas é menos estável do que parece, abrindo todo um campo de debates sobre os limites internos da obra e a forma de edição dos poemas. Martha Nell Smith, aliás, é uma das cabeças por trás do grandioso trabalho de digitalização e abertura pública dos manuscritos de Emily Dickinson na internet. ${ }^{4} \mathrm{O}$ processo interativo da internet possibilitou que os manuscritos fossem "lidos" tanto a partir de uma transcrição "diplomática” quanto de uma transcrição linear (em versos), o que fomentou toda uma discussão sobre a questão da "visualidade" e o "aspecto gráfico" dos poemas.

\section{Dos fólios aos fascículos}

Nessa mesma linha de Hart e Smith, Marta Werner (1988) publica os "open folios", textos que não se enquadravam nem como cartas nem como poemas, equestiona ainda mais, em sua apresentação crítica, a estabilidade do texto dickinsoniano. Seguindo a linha feminista de Cameron, Hart e Smith, Werner demonstra como os "excessos" e os "desvios" da escrita dickinsoniana foram sendo recalcados por um aparato crítico-textual masculino e repressor, quando a escritora copiava e recopiava os textos, modificando-os, justamente por não almejar uma forma definida. Eis como Werner (1988, p. 27-28) descreve o trabalho de crítica textual das cartas por Johnson:

4 Disponível em: <emilydickinson.org>. 
[...] mediated by a flotilla of dates, names and scholarly annotations, even the wild and beautiful irresolution of the late compositions vanishes. Moreover, in the haste to superimpose his scholarly apparatus and ideology of the definitive text over her anticanonical aesthetics of radical variation, Thomas $\mathrm{H}$. Johnson also overlooked Dickinson's incarnational poetics and her conversion of the very aims of copying. For Dickinson the aim of copying is neither greater "legibility" - the production of a "fine hand" - nor the government of a multiplicity of hands in conformity with a prescribed model. Rather, the event of copying constitutes a mysterious and sensuous form of translation in which trans-, the carrying across of a message, is also always carrying away and an abandonment of that message in the arms of alterity's angel. ${ }^{5}$

Com edição dos "open folios" [fólios abertos] e, mais recentemente, dos "envelope poems" [poemas-envelope], Bervin e Werner (2013) abriu uma cisão ainda mais profunda entre os fascículos e os textos tardios de $\mathrm{ED}$, em que a forma do "poema" perde seus contornos, transformando-se em forma visual, aberta, múltipla - o que também projeta ainda mais a sua poesia para o campo da modernidade. Considere-se, por exemplo, o fragmento A746 (WERNER, 1988, p. 55):

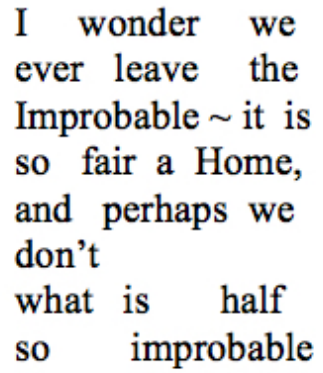

\author{
Imagino se a gente \\ alguma vez sai do \\ Improvável é uma \\ Casa tão bonita, \\ e talvez a gente \\ nem \\ o que também é \\ meio improvável
}

\footnotetext{
5 “[...] mediada por uma flotilha de datas, nomes e anotações eruditas, até mesmo a bela irresolução das composições tardias desaparece. Mais que isso, na pressa de impor seu aparato erudito e a ideologia do texto definitivo sobre a estética anticanônica da variação radical, Thomas $\mathrm{H}$. Johnson também desconsiderou a poética incorporante de Dickinson e o seu desejo de ter cópias [dos poemas]. Para Dickinson, o desejo de cópias não se deve nem a uma maior 'legibilidade' - a produção de uma 'caligrafia firme' - nem ao governo de uma multiplicidade de caligrafias em conformidade com um modelo prescrito. Antes, o evento das cópias constitui-se como uma misteriosa e sensual forma de tradução, na qual o trans-, o levar a mensagem através, é também um levar para fora e um abandono da mensagem nas mãos de um anjo da alteridade."
} 
Não apenas a fragmentação, com lacunas sintáticas e semânticas, mas a própria forma gráfica parece corroborar uma curiosa relação entre o sentido e a materialidade. Trata-se de um poema ou de uma nota? Um Rabisco? Um fragmento filosófico? Um poema concreto? Fica então a questão de como "transcrever" esse texto se não for respeitando a sua própria instabilidade gráfico-sintático-semântica, ou seja, buscando uma tradução gráfica que seja o "anjo da alteridade", como assevera apropriadamente Marta Werner. Pode-se imaginar já implicações disso para a tradução do texto dickinsoniano para outras línguas. Não é precisamente o tradutor esse anjo da alteridade?

Apesar de toda a indeterminação, há de admitir que há zonas de estabilidade. Uma delas, como queremos mostrar aqui, é a existência dos fascículos. Mais do que sua mera existência, demonstrar que eles nos permitem entender como ED percebia a relação entre sua obra e o público, ao mesmo tempo em que percebia as relações internas na sua obra (por exemplo, entre um poema e outro, entre um conjunto de poemas e outro). Segundo Sharon Cameron (1992), os fascículos nos permitem compreender melhor aquilo que caracteriza a atitude de ED diante de sua obra, que se define bem na expressão que dá título ao livro de Cameron: choosing not choosing.

Segundo Cameron (1992, pp. 54-56), ED escolheu não escolher, talvez porque não pudesse ou não quisesse escolher uma forma definitiva para uma obra que, internamente, se modificava e perdia seus contornos. A autora argumenta que é às vezes é difícil não apenas perceber os limites que separam um poema do outro, mas também os de sequências de poemas em relação a outras sequências. E esses limites se tornavam mais imprecisos na medida em que ela recopiava os poemas e os deslocava de um fascículo para outro, ou mantinha o mesmo poema em dois fascículos distintos. Por outro lado, nos próprios poemas, tomados isoladamente, parece faltar uma "narrativa interna" (CAMERON, 1992, p. 55) que lhes conceda alguma autonomia em relação aos demais. Tudo somado, a estrutura dos fascículos - assim como de toda a obra, inclusive as cartas - parece estar tomada de uma "indecidibilidade" interna, que torna qualquer delimitação questionável (como, por exemplo, as delimitações por números e datas das edições de Johnson e Franklin).

Então, já que a obra de ED é internamente "indecidível” (não apenas do ponto de vista hermenêutico, mas material), como editá-la, e como traduzi-la? Antes de responder a essa questão, temos que saber como se 
pode ler um poema de ED, qualquer poema de ED. Cristanne Miller (1987) já tinha chamado a atenção para o modo como as lacunas e modificações sintáticas (elipses, inversões) geravam instabilidades na leitura dos poemas, gerando uma "ungrammar". Essa instabilidade se via agravada pelo uso inusitado das maiúsculas e por referências intertextuais as mais diversas, sobretudo quando combinadas (por exemplo, textos da Bíblia e de Shakespeare). O efeito geral dos poemas de Dickinson é, então, o de uma retração semântica: ao invés de expandir o sentido através da polissemia, seus poemas parecem retirar ao leitor parte do sentido que ele espera ou presume. Isso ocorre ao mesmo tempo em que ela anuncia grandes temas, como a morte, o amor, a imortalidade. Curiosamente, a compressão sintática e a economia semântica parecem criar uma estranha forma de promessa: como uma promessa de possibilidades, tal como a que se inscreve neste verso: "I dwell in Possibility -" [F466A; J657]. ${ }^{6}$

Dito isso, a leitura dos fascículos, associada com a leitura do contexto histórico (MILLER, 2012) permite-nos algumas possibilidades. Tomemos por exemplo o poema "I asked no other thing -"7 [F687A; J621], incluindo as alternativas, à direita:

I asked no other thing -

No other - was denied -

I offered Being - for it -

The Mighty Merchant sneered -

[Merchant] smiled -

Brazil? He twirled a Button -

Without a glance my way -

"But - Madam - is there nothing else -

That We can show - Today"?

6 Seguindo o padrão da Emily Dickinson Internacional Society, os poemas de Emily Dickinson vêm sempre citados a partir do primeiro verso (incluindo a capitalização "peculiar" e pontuação no final), sempre no original, seguidos da numeração que receberam nas edições críticas de R.W. Franklin [F] e T.H. Johnson [J]; de 2016 para cá, a tendência da crítica tem sido a de desconsiderar a edição de Johnson, já desacreditada por muitos, e citar apenas a de Cristanne Miller [M] seguida da numeração de página. Os poemas da edição de C. Miller serão citados aqui com as abreviações "Fs" para fascículo e "Fo" para folha.

7 ED criou as suas próprias convenções, muitas vezes inexplicáveis, de usar maiúsculas e minúsculas, não raro capitalizando até verbos ou preposições. O padrão da área é respeitar essa peculiaridade tanto na citação do título quanto na transcrição dos originais. $\mathrm{O}$ tradutor, evidentemente, deve recriar, em sua língua, tais convenções, que nem sempre serão idênticas às do texto de partida. 
Não pedi nada mais -

Nada mais - foi negado -

Ofereci Existir - ao Poderoso

Mercante - que riu de um lado -

[que] sorriu -

Brasil? - girando um Botão -

Sem sequer me encarar -

"Mas Dona - não há outra coisa

Que lhe possa - mostrar"?

Solto, esse poema pouco diz sobre o porquê da escolha do Brasil. Vejamos primeiro como se estabelece a costura semântica. Em primeiro lugar, o contexto. A crítica de ED sabe que seu conhecimento sobre as ciências em sua época era bastante avançado. Não é de se estranhar que seu conhecimento geográfico fosse surpreendente. Mas sua visão do estrangeiro está marcada por um "orientalismo" característico do século XIX (MILLER, 2012). Em geral, o seu "oriente" são as terras distantes e exóticas, onde tudo é rico e perfeito. No que diz respeito a esse poema, o "orientalismo" de ED está contaminado por aquilo que Sérgio Buarque de Hollanda descreveu como uma visão do paraíso.

Dito isso, passemos ao cotexto. Primeiro, no cotexto geral da obra, o Brasil aparece em quatro poemas de ED. Em "Some such Butterfly be seen" [F661A; J541], ela menciona uma borboleta que se vê "nos pampas do Brasil", associada às ideias de beleza rara e fugacidade; em "A moth the hue of this" [F934; J840], uma certa mariposa matizada gira em torno de "velas no Brasil" e serve para provar que a natureza se enfeita como uma mulher; enfim, no poema "My first well day - since many ill - [F288B; J574; CM Fs28; Fo5], a narradora, saindo de uma convalescência, se admira da força e do cuidado estético do Verão, que

Passou a enfeitar Castanhas -

A tudo dando um Tom faceiro -

Vestiu Sementes com toucas -

E jogou um Bordado Brasileiro

O termo "Brazilian Thread" é um tipo de fio usado em bordados, conhecido pela maleabilidade e pelo colorido, e serve para alegorizar a força criativa do verão (da natureza). Em termos do cotexto mais específico, o que importa é a relação entre o bordado (o universo da costura) e o fascículo ao qual pertence esse poema. Nesse fascículo, um dos poemas centrais - pelo seu caráter reflexivo - é justamente um poema sobre a relação entre a escrita, a doença e o bordado, ou seja, sobre a escrita e a 
condição feminina. Trata-se do poema "Don't put up my Thread \& Needle -" [F681A; J617], cujas três primeiras estrofes são estas:

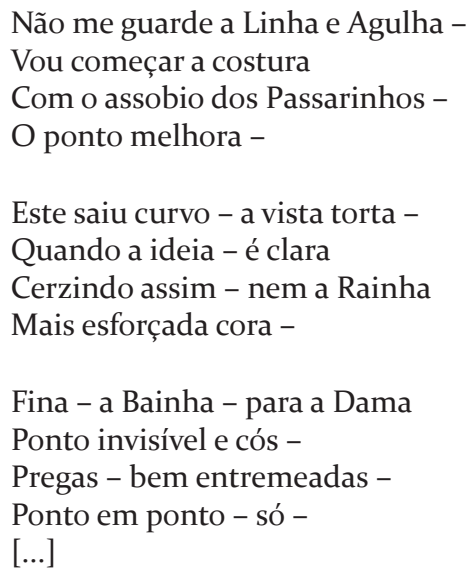

Não vou desfiar aqui toda a história das imagens da tessitura e da poesia, desde os mitos de Aracne e Penélope. Quero apenas reforçar a ideia de que a dupla tessitura (da poesia e do bordado) aponta para uma noção de escrita feminina que é notável em Emily Dickinson. Aliás, toda a dimensão do trabalho doméstico (inclusive com o jardim) vem à tona em sua obra, criando uma imagem da condição feminina da escritora e da própria escrita. É esse universo, associado com o "orientalismo", que constitui o pano de fundo do poema "I asked no other thing", pois a sua narrativa se estrutura sobre uma cena cotidiana, da mulher comprando tecidos. Já sabemos que esse tecido raro, o Brasil, representa o impossível, o inatingível, o desejo. O Brasil aí é a visão do paraíso, mas não será também a visão do Paraíso, com maiúsculas? E quem é, aliás, o Poderoso Mercador?

Para entender esses dois termos, o Paraíso e o Poderoso Mercador, temos que inserir o poema no seu cotexto mais específico, que é o fascículo 32, onde está também o mencionado poema sobre o bordado. Nesse fascículo, como em outros do ano de 1863, em que a produção de ED atinge o seu pico (295 poemas), a expressão mística também atinge seu cume. Vale lembrar que, embora a atitude mística e sua expressão estejam ligadas ao surgimento das religiões (e não apenas da cristã), o místico não se reduz ao religioso, parecendo bem mais rebelar-se contra os dogmas. Como bem aponta Eduardo Losso (2016, p. 19), citando Jorge de Lima, o místico é um "incontentável”, mas essa atitude de não resignação encontra 
na "ataraxia ascética" a capacidade de suportar o sofrimento. Vale lembrar ainda que a atitude mística produziu grandes obras literárias, como as de Teresa de Ávila, João da Cruz e Sor Juana Inés de la Cruz. No caso desses autores, a busca da unio mystica com o transcendente leva a que a fé encontre uma forma material, forma esta que se expressa no ato criativo como complementaridade do êxtase e da razão.

Em ED, sabemos, a religiosidadeé difusa, influenciada pelo calvinismo jansenista de Jonathan Edwards, que vê na crença uma conduta ética, que busca a Graça através do autoaperfeiçoamento moral. Ora, esse é também um objetivo dos transcendentalistas americanos, particularmente de R. W. Emerson, que ED conheceu pessoalmente e a quem leu em profundidade (tanto a poesia quanto os ensaios).

Assim, na obra de ED, particularmente no fascículo 32, o Paraíso é algo que se deseja e se busca, e não algo que está num passado remoto e perdido. Nessa busca, as coisas criadas - a natureza - são portais para a Eternidade. Em outros termos, só se chega à Eternidade (e ao Paraíso) através do mundo material. ${ }^{8} \mathrm{O}$ primeiro verso do poema F69o [CM Fs32, Fo3] sintetiza esta ideia: "Forever - is composed of Nows". Não se chega à Eternidade senão passando pela porta do Instante, do Agora. Nesse sentido, o místico se opõe ao religioso: enquanto este último vende a ideia de que só o além interessa ("Só Jesus Salva”), o místico puritano acredita que é o aquém que interessa: você só se salva aqui. É verdade que Cristo disse que seu Reino não é deste mundo, mas também disse que é preciso dar a César o que é de César.

O problema maior é a morte. Como mística puritana, ED não sabe onde colocar a morte, por isso Ela a atormenta tanto. Não tanto pela dor, mas pelo que vem depois. A morte interrompe a busca do Paraíso que já está na variedade e na beleza da criação divina - nesta vida, sobretudo na natureza. A morte nos lança no desconhecido da Eternidade. Então, o que a atormenta mais é a Eternidade. Porque a ideia de Eternidade é a da repetição incessante do mesmo. A eternidade é o tédio. No poema $I$ know Where Wells grow - Droughtless Wells - [F695A; J46o; CM Fs32 Fo5], por exemplo, a poeta descreve o mundo divino com uma imagem bíblica: no mundo de lá, há poços excelentes, com água farta e brilhos diamantinos. No mundo de lá, não haverá sede (ela cita João 4, 13-14):

8 Essa busca de uma mística da e na natureza é romântica, mas é sobretudo particular do transcendentalismo americano, sendo, nesse caso, H.D. Thoreau a influência mais decisiva sobre ED. 
O povo lá "não terá sede",

Leio num Livro Antiquado -

Poços com Baldes há pra eles -

Deve ser esse - o significado -

Mas como lembrar - Nossa Seca?

Aquela Água é tão Grande -

Um Pocinho assim - o Meu -

Acho - melhor se entende -

Daqui se entende por que ED quer o Brasil. Ela quer o "paraíso terreal", a possibilidade de um poço infinito na vida, no reino deste mundo. Aqui também fica mais fácil supor quem seria o Poderoso Mercador. Nessa expressão, fundem-se os dois livros que Emily Dickinson mais leu e citou: a Bíblia e Shakespeare (além do Dicionário Webster, que faz a ponte entre os dois). O adjetivo "Mighty" lembra o bíblico "God Almighty", ao passo que o "Mercador" nos remete ao Mercador de Veneza. Deus e Shylock. Deus é Shylock? Talvez por isso mesmo o Mercador ria ironicamente do desejo da "Dona", enquanto fica girando os botões (pensando com seus botões). Ela quer apenas e simplesmente o impossível: o Brasil. É nesse querer e nesse desejar que repousa a ética mística e a mística poética de Emily Dickinson. É um querer e um desejar que não reconhecem como justos os limites impostos a ela, sobretudo pelo Pai (e por aqueles que falam em Seu nome, que ela tanto mais despreza). No entanto, como se sabe, ela jamais deixou a casa do Pai. Preferiu, talvez, refazê-la por dentro (transfazê-la em sua "refazenda"), trazendo para dentro dela as especiarias estrangeiras, os aromas orientais, desconfigurando a sua pureza puritana. Emily Dickinson foi, talvez, a última puritana. Porque ela própria destruiu o pesado rastro de puritanismo que vinha atrás dela (na literatura, pelo menos). Ou melhor, o desconstruiu. É o que também faz Hawthorne e, sobretudo, o último Melville, seu anônimo e verdadeiro contemporâneo.

\section{A SUTURA}

A publicação dos fascículos e dos manuscritos de Emily Dickinson tem levantado cada vez mais discussões em torno do caráter movente da escrita dickinsoniana. A questão que se coloca para o editor - e também para o tradutor - é: como manter a coerência da obra sem violentar a sua movência? Como fazer com queaquilo que recusa manter-se estável, aquilo que quer manter-se na sua alteridade, possa ser lido, editado, traduzido? Há alguns caminhos ou modelos de edição. O primeiro modelo é o da 
apresentação de fac-símiles, os Manuscript Books. Foi esse o modelo usado por Franklin, na edição dos fascículos. Essa edição monumental (e extremamente cara) foi fundamental para estabelecer novos critérios de edição da obra de ED, mas se tornou ilegível para não especialistas. Evidentemente, é também uma obra intraduzível. O trabalho de Marta Werner (dos "open folios" aos "envelope poems") também apresenta os fac-símiles, mas propõe uma transcrição diplomática dos mesmos, respeitando as quebras de linha originais, as inserções de alternativas nas entrelinhas (ou nas laterais do texto) ou no final do texto (com a marca + ), e principalmente a transcrição das rasuras. O segundo modelo é o das edições variorum de Franklin e Johnson: os poemas são datados e numerados, eapresentados com todas as suas variantes, com as alternativas e modificações, além de um aparato crítico-histórico para cada poema. Em ambos os casos, os manuscritos dos poemas foram submetidos a uma "formatação" (nos manuscritos, muitas vezes o verso "salta" de uma linha para outra, por questão de espaço) capaz de recompor os versos de acordo com o que se supõe ser a prosódia "natural" de ED (sobretudo o common metre $\left.{ }^{9}\right)$. O terceiro modelo é dado pelas edições de leitura [reading editions]: elas são nada mais do que reduções das edições variorum, com a eliminação das variantes e a redução das alternativas. Um quarto modelo é a edição "interativa” da poesia de ED, no site <emilydickinson.org>.

A edição dos Poems as She Preserved Them, de Cristanne Miller, segue um caminho novo, que, a meu ver, integra os demais. Em primeiro lugar, ela segue o modelo dos Manuscript Books, respeitando a integridade dos fascículos, das folhas soltas etc. Mas os manuscritos foram transcritos e editados em uma forma legível ao público (reading edition), sem prejuízo das alternativas (apresentadas na lateral do texto). As variantes só foram incorporadas quando eram cópias retidas pela autora (isto é, quando apareciam em fascículos ou folhas diferentes). As demais variantes (enviadas por cartas, ou transcritas por terceiros, ou perdidas) foram indicadas em nota de rodapé. Vale destacar que os poemas não são numerados, mas seguem, antes, a forma e a ordem de apresentação nos manuscritos. É essa a edição que seguimos, pois acreditamos ser nela que se realiza a costura do texto, sem que fique obstruída a possibilidade da sua sutura - inclusive pela tradução. Vejamos por que.

\footnotetext{
9 Tipo de verso bastante popular na literatura de língua inglesa do século XIX, em hinos protestantes e em canções populares. Sua forma silábica básica é o verso de 8.6.8.6, geralmente em pés jâmbicos, quase sempre com rimas pares.
} 
O ponto partida do conceito de sutura, tal como usado por JeanPierre Oudart (1977), vem da psicanálise lacaniana, mais especificamente de Jacques-Alain Miller (1966). Em ambos os casos, o conceito de sutura serve para definir um "campo" específico: o propriamente psicanalítico da psicanálise e o cinemático do cinema (este último, por oposição ao fílmico). Esse campo é definido por Miller (1966) como o da "lógica do significante".

No cinema, segundo Oudart (1977), o cinemático é o cinema per se, para além do cinema enquanto a soma dos objetos filmados e montados em planos sucessivos. O cinemático se constitui enquanto uma "cadeia de significantes" sempre marcada por uma Ausência: o espectador e seu olhar, mas também a própria situação cinema (a "quarta parede", o invisível e apenas suposto no "fora do plano" etc.). Afinal, é nessa Ausência que se revela o "sujeito", o "Outro" que "fala" na cadeia de significantes do filme, e a sua relação com o plano do Imaginário. Ademais, seguindo as ideias de Lacan, um signo não é aquilo que está no lugar de outra coisa, mas aquilo que representa algo para alguém: o que interessa é a relação entre um significante e outro, mais do que a relação entre significante e significado, já que essa relação é sempre marcada por uma Ausência. A sutura é, pois, na cadeia de significação cinemática, a possibilidade de fazer emergir essa Ausência, que oscila como um "pulsar em eclipse", ou como puro desejo (OUDART, 1977, pp. 42-43).

A sutura é ainda o significante de uma Ausência, desse Outro que é o espectador, na sua posição passiva e ativa, e também um Outro, que não pode ser identificado como sujeito, senão como sujeito de uma Ausência, que remete ao Imaginário. A sutura é justamente o modo como se pode ver a emergência desse sujeito. Conforme Jacques-Allain Miller, jogando com a palavra "lieutenant" [tenente], formada a partir de "lieu" [lugar] e "tenant” [tenente, substituto]:

\begin{abstract}
A sutura nomeia a relação do sujeito com o encadeamento de seu discurso [...] [o sujeito] figura nesse encadeamento como o elemento que falta, sob a espécie de um tenente-do-lugar [tenant-lieu]. Pois, uma vez que faz falta nele, ele não está simplesmente ausente dele. Por extensão é sutura a relação em geral da falta na estrutura de que ele [o sujeito] faz parte, na medida em que implica a posição de um lugar-tenente. (MILLER, 1966, p. 39) ${ }^{10}$
\end{abstract}

10 "La suture nomme le rapport du sujet à la chaîne de son discours; on verra qu'il y figure comme l'élément qui manque, sous l'espèce d'un tenant-lieu. Car, y manquant, il n'en est pas purement et simplement absent. Suture par extension, le rapport en général du manque à la structure dont il est l'élément, en tant qu'il implique position d'un tenant-lieu." 
O que tudo isso tem a ver com Emily Dickinson? Como dissemos, trata-se de uma obra ainda em estado de movência. Do manuscrito à transcrição, há sempre algo que se perde. E talvez esse algo seja mesmo inacessível. Talvez ele seja uma Ausência. A sutura tenta recolocar essa Ausência inatingível do "sujeito" no encadeamento do seu discurso, ao invés de imputar-lhe uma significação (e uma forma) estável. Do mesmo modo, a leitura, agora, passa a ser não a busca de um significado, mas um prazer de jogar o texto na sua estrutura furada, vazada, e virtual. A tradução, por sua vez, e sobretudo a edição-tradução, realiza uma nova sutura, criando algo como uma proliferação de significantes, que tanto mais aumenta o gozo do texto.

\section{COSTURA E SUTURA (TRADUÇÃO)}

Como vimos acima, os processos de costura e sutura operam sobre o modo como se pode traduzir uma obra em movência, isto é: a) uma obra cujo "texto definitivo" não existe ou ainda se encontra em processo de discussão crítico-textual; b) uma obra que, ela mesma, internamente, questiona a sua própria existência enquanto obra, pois está fundada num gesto de "escolher não escolher"; c) uma obra vazada, porosa, cheia de lacunas, variantes, alternativas. Como mostramos, os processos de costura e sutura obrigam o tradutor a entrar no seio da discussão interpretativa (bibliografia crítica e biográfica) e também da crítica textual (estabelecimento do texto), convertendo-se ele também em um editor tarefa que, como vimos, também é atribuída a qualquer leitor dessa obra. Resta ainda demonstrar como se procede à tradução dos poemas.

A primeira questão que se levanta é a de saber o que é um poema. E essa questão não pode ser respondida a contento, pelo menos aqui, pois ela pressupõe uma discussão quase infinita e uma bibliografia que encheria uma biblioteca. Queria apenas lembrar uma delas, a que é dada por Paul Valéry e que me parece a mais condizente com a poesia de ED. Em "Poesia e pensamento abstrato", Valéry (1957) apresenta algumas ideias sobre a situação de comunicação verbal. No discurso não poético, o processo de dizer se dissipa, uma vez que a mensagem é compreendida pelo interlocutor. No poema, ao contrário, há uma força de conservação; na poesia, a mensagem quer conservar-se na própria forma do enunciado. E o que cria essa força de conservação? O ritmo, responde Valéry. O ritmo impõe ao enunciado poético uma estranha "oscilação entre o som e o sentido". 
O mesmo Valéry, ao comentar suas traduções das Bucólicas de Virgílio, demonstra sua busca por certo tipo de verso e certo tipo de ritmo. Mas é sobretudo num texto menor de Varieté, "Cantiques Spirituels", que a posição estética de Valéry (1957) pode ser associada a uma posição ética. Trata-se de um comentário sobre uma tradução francesa dos poemas místicos de São João da Cruz. Tal como fez na apresentação das Bucólicas, em que confessou não ser latinista nem ter apreço especial pela poesia pastoril, Valéry confessa que tem pouco interesse pela questão do místico. Contudo, ele se impressiona com a descoberta desses textos, traduzidos por um monge carmelita descalço, Cyprian Nativité de La Vierge, na metade do século XVII. Por um lado, ele destaca, no trabalho do quase anônimo carmelita, os comentários ao texto: "a melodia sagrada vem acompanhada de um erudito contraponto que tece em torno do canto todo um sistema de disciplina interior" (VALÉRY, 1957, p. 447). Mas é sobretudo a tradução do carmelita que o espanta. Antes mesmo de referir-se ao texto como uma tradução, Valéry (1957, p. 450) o considera como um poema, e, como tal

\begin{abstract}
Esse texto, de repente, não é daqueles que se oferecem para nos ensinar alguma coisa, e para se desfazerem [s'évanouir] diante da coisa compreendida; mas ele age para nos fazer viver alguma vida diferente, respirar de acordo com essa segunda vida [vie seconde] e supõe um estado ou um mundo em que os objetos e os seres que nele se encontram, ou antes suas imagens, tenham outras liberdades e outras ligações diferentes das do nosso mundo prático. Os nomes dessas imagens desempenham a partir daí um papel em seu destino: e os pensamentos sempre obedecem à sorte que lhes designa a sonoridade ou o número de sílabas desses sons..."
\end{abstract}

Mesmo declarando-se não místico, o autor vai exaltar na tradução exatamente aquilo que os místicos, como João da Cruz e Teresa de Ávila, descrevem como o êxtase (ou o estado do nunc stans). Ao mesmo tempo, Valéry percebe uma articulação essencial entre ritmo, imagem e pensamento (v. MÜLLER, 2017), e o modo como esses elementos levam a uma segunda vida. Daí, ele passa a comparar original e tradução. Apesar de confessar seu pouco conhecimento do espanhol, destaca, no trabalho do tradutor, a capacidade de "cantar para a orelha francesa" (VALÉRY, 1957, p. 415), até que estabelece uma formulação conceitual:

11 "Ce texte, sur-le-champ, n'est plus de ceux qui sont offerts pour nous apprendre quelque chose, et pour s'évanouir devant cette chose comprise; mais il agit pour nous faire vivre quelque différente vie, respirer selon cette vie seconde, et supposer un état ou un monde dans lequel les objets et les êtres qui s'y trouvent, ou plutôt leurs images, ont d'autres libertés et d'autres liaisons que celle du monde pratique." 
Isso é verdadeiramente traduzir, que é reconstituir da forma mais próxima o efeito de uma certa causa, - aqui, um texto em língua espanhola, por meio de uma outra causa, - um texto em língua francesa. (VALÉRY, 1957, p. 451)12

Como discípulo de Mallarmé, e, consequentemente, de Edgar Allan Poe, Valéry é um predecessor da teoria do efeito estético. Aliás, além de discorrer sobre poesia e sobre tradução, ele também descreve o ato da leitura; ou, como o leitor se posiciona eticamente diante de um texto alheio. O leitor, diz Valéry (1957, pp. 452-453), transforma todo texto num texto anônimo, "como sem autor". Mas isso ocorre na medida em que o texto prepara esse efeito, em que ele busca o estado de perfeição: "O que eu chamo de Perfeição elimina a pessoa do autor" (p. 453).

Deixando de lado todas as ressonâncias desse texto sobre a questão do autor, vejamos o que ele diz sobre o tradutor. "A pessoa do Frade Cyprien é singularmente imperceptível" e "[sua obra] permaneceu [...] velada até nossos dias” (VALÉRY, 1957, p. 453, grifo nosso). O autor se espanta que o frade tenha morrido no quase anonimato e seja um desconhecido nas letras francesas. Evidentemente, o leitor francês conhece São João da Cruz, o autor de "Cantiques Spirituels". Mas por que desconhece o tradutor? Porque a obra do carmelita está subsumida no texto de São João da Cruz. Deste são "as ideias, as imagens, a escolha dos termos" (p. 455). Mas a obra daquele é "la façon de la forme" [o modo da forma] (p. 454). Este, o escritor João da Cruz tem a liberdade de escolher os termos, as imagens, as ideias. Aquele, o carmelita, o tradutor, tem o "dever de dançar estando acorrentado" [devoir danser étant chargé de chaînes] (VALÉRY, 1957, p. 455).

Como vemos, a tarefa do tradutor impõe uma disciplina e um limite. Mais ainda, em se tratando de um poema. É uma questão ética. Mas nem por isso, menos estética. Nem por isso, menos política.

A outra questão que cabe colocar aqui é: o que é um poema no conjunto da produção textual de ED? A resposta a essa questão envolve processos de costura e sutura. Por exemplo, para constituir o corpus de quase 1.800 poemas, T. H. Johnson teve que retirar fragmentos de textos que estavam nas cartas de ED. Posteriormente, Marta Werner mostrou que algumas cartas que Johnson não considerou também eram poemas. Mais recentemente, Werner editou os "envelope poems", que foram

12 "C'est là véritablement traduire, qui est de reconstituer au plus près l'effet d'une certaine cause, - ici un texte de langue espagnole au moyen d'une autre cause, - un texte de langue française." 
recuperados de rabiscos feitos por ED em envelopes usados. Nas cartas de $\mathrm{ED}$, percebe-se que há muita poesia, e até mesmo em suas receitas de bolo se encontram "raspas" de poesia. Então, como e onde procurar a poesia?

Se analisarmos os fascículos de ED, podemos observar certos padrões. O primeiro deles diz respeito ao ritmo, mais especificamente à prosódia. Em mais de 90\% dos casos, ED usa apenas dois tipos de verso: oito e seis sílabas, predominantemente em pés iâmbicos. Cristanne Miller demonstrou que o uso dessa medida, o common metre, não era exclusivo de ED, mas da maioria dos poetas americanos do período anterior à Guerra Civil. Além do mais, o common metre de duas a quatro estrofes é o padrão do hinário protestante e se enraíza profundamente na vida e na poesia de ED.

Além do common metre, uma segunda característica formal é dominante em mais de 9o\% dos poemas: o uso das rimas. Ao contrário do metro, que mantém uma constância, o uso das rimas é mais variegado. Em geral, se considerarmos " $x$ " o elemento que não rima, o esquema é sempre $x A x A x B x B \times C x C$, ou seja, sempre rimam os versos ímpares, de forma cruzada (um padrão que também vem do hinário protestante). Mas é possível acontecer também que apenas uma das estrofes (geralmente a final) esteja com rimas (é bastante comum, por exemplo, xXxX xAxA). Quanto ao tipo de rima, ED tinha predileção pela rima rara (elementos sintáticos distintos), e sobretudo pela "slant rhyme", que equivale à nossa rima toante (Prayer/Despair; become/Sum; Blue/too).

Um segundo elemento importante do ritmo de ED é a pontuação. $\mathrm{O}$ uso dos travessões pode servir para criar pausas ou cesuras, e altera o andamento normal do percurso entoativo. Os "dashes" [travessões] também podem servir para manter certa "abertura" interpretativa, principalmente quando ocorrem no final do poema. Pode ocorrer que a pontuação seja usada de forma semântica, como o ponto-final que aparece na última estrofe do poema "Pain - Has an Element of Blank" (ver anexo), justamente depois da palavra "Period", que também significa "ponto final". Enfim, não menos importante para o ritmo específico da poesia de ED são as inversões e as elipses. Estas não são apenas elipses sintáticas de alguns termos. Muitas vezes elas suprimem uma série de termos, tonando a frase quase incompreensível. Outras vezes eliminam as conjunções ou elementos que alteram o modo verbal (no inglês, por exemplo, os verbos auxiliares "could" e "would"). 
Vale lembrar, ainda, que a língua inglesa é muito mais sintética que a portuguesa e, naturalmente, dispensa termos que a língua portuguesa considera essenciais, como as conjunções subordinativas (como em "I think he is not coming" [eu acho que ele não vem]) ou aglomerando locuções verbais ("she would have" = "she'd've") [ela teria] e, sobretudo, ao dispensar a proposição de, ou pelo uso de apóstrofe ("God's will”) [vontade de Deus] ou pela mera e natural anteposição do determinante ("translation studies" [estudos da tradução]). O que ED faz é forçar ainda mais a língua inglesa à síntese, talvez por uma necessidade de condensação ligada a uma ideia de economia que contrasta com poetas de sua época, como Walt Whitman. Além das elipses, o uso da inversão sintática em ED obedece a um duplo critério: tanto pela adequação do discurso ao andamento do verso (ou seja, por razões métricas), quanto por um modo de criar dissenções e dúvidas dentro do próprio discurso. Assim, observemos um curtíssimo poema [F850A; J730]:

Defrauded I a Buterfly -

The Lawful Heir - for Thee -

A inversão ("I defrauded a buterfly") se deve primariamente a uma questão métrica (para manter o tetrâmetro iâmbico) e prosódica (a rima interna I/Y no segundo e quarto pés). Mas, além da inversão, ED também afasta o objeto indireto ("for Thee"), intercalando a oração adjetiva de forma elíptica (sem o "that is" antes de "the Lawful Heir"), tudo pontuado pelos travessões, que criam um ritmo secundário (pausas) dentro do ritmo. Se a tradução quisesse cobrir as lacunas e corrigir as inversões, teríamos algo como: "Eu defraudei a borboleta por ti, que era a herdeira legal”, ou em verso:

[Eu] defraudei a Borboleta -

Que era a Herdeira Legal - Por Ti

É verdade que o pensamento se mantém, mas o ritmo vai para o espaço e, com ele, uma parte da imagem, que, mais do que uma imagem estável (que seria impossível, pois não há como "defraudar" uma borboleta), é algo como um bruxuleio de imagem. Daí que o tradutor, se quisesse levar o leitor até a fonte (fonte de águas obscuras, é certo), teria que fazer algo como:

A Borboleta burlei -

Por Ti - A Herdeira por Lei - 
Embora uma nova inversão (no texto traduzido) crie outra ambiguidade (quem era a herdeira?), mas não deixa de ser justa com o ritmo. Note-se também que optei por deixar o termo "heir" no feminino. Essa é uma questão central na poesia de ED, a relação entre gênero gramatical e gênero. Mesmo sabendo que a palavra "Butterfly" não é necessariamente feminina, do ponto de vista gramatical. Mas, seguindo uma longa discussão sobre o feminino em ED e a relação entre ED e Susan Gilbert Dickinson, entendo que a maioria dos poemas de ED que associam lírica amorosa e natureza foram dedicados a Susan e/ou a amigas de ED. Mais do que isso, pensando em uma política da tradução (SPIVAK, 200o), quero destacar que traduzo a poesia de ED primeiramente para as leitoras de ED, e não para um leitor geral. Dito de outra forma - e seguindo Spivak (2000) -, adoto uma posição feminista ao traduzir o poema acima e a poesia de ED como um todo. De outro modo, por exemplo, se traduzisse "heir" por herdeiro, estaria caindo novamente numa distinção de gênero, mesmo que se argumentasse que o masculino é o universal - o que, por si, já é uma atitude falocêntrica.

Mais do que a mera questão gramatical, quero ressaltar a questão ética implicada na tradução desse poema. A questão que se me coloca é: quem é que fala aqui, a quem? Quem é o sujeito do poema, e quem é o ou a herdeiro(a)? Como se depreende da leitura, trata-se de um "defraudar". No Webster de 1844, temos as seguintes definições: "Swindle; beguile; cheat; rob; unjustly deprive; unfairly dispossess". O sujeito(a) voz que fala nesse poema assume, de cara, uma contravenção, um ato contra naturam, ou seja, a natureza foi enganada, burlada, defenestrada (inclusive com a conotação erótica). O sujeito(a) voz se assume como responsável por tal "ilícito", por tal inversão/diversão, que se apresenta como inversão sintática. Inversão? Sim. Em todos os sentidos. O que se enuncia aqui é o prazer, não apenas de burlar, mas de burlar por uma outra pessoa, em nome dessa outra pessoa. E não se trata de fraudar letras de câmbio ou contratos. É a própria natureza que está sendo defraudada. Nessa fraude de letras, o poema rouba as cores da borboleta e se oferece, em câmbio, como arroubo, a alguém. Evidentemente, uma fraude estética, de quem pensa antes a beleza. Ora, essa relação entre natureza (a borboleta) e o artifício (a fraude) atravessa a poesia de ED e remete quase sempre para o campo do feminino, ou melhor, para o corpo feminino. Um corpo que não quer aceitar a natureza como fato, como estabilidade, mas, antes, como processo, como movência. Por isso mesmo, assumir uma posição 
feminista é uma condição ética que se impõe ao tradutor, ele terá que burlar as regras (sobretudo as gramaticais!), terá que ser infiel à letra A, para tentar se aproximar da letra a (o deslize infinito do significante). Ao mesmo tempo, o tradutor burla a lei do original para dar ao leitor as cores de um novo poema, modificando os termos legais do contrato: o herdeiro do texto passa a ser o leitor. Essa é uma operação de sutura.

\section{STITCH AND SUTURE: TRANSLATING AND EDITING EMILY} DICKINSON'S FASCICLESAbstract: Since the early publications of Emily Dickinson's writings, they have been subject to alterations, distortions and erasures along with many frustrated or unsuccessful attempts to preserve the idiosyncrasy of her style when edited. Until now, different versions of her works have been commercially available in bookstores. For the translator, this instability poses the problem of defining which is the original he is supposed to deal with. Therefore, I propose here a methodology of translation consisting of two attitudes: stich and suture. By stitching, the translator plays an active role in the editorial choices in order to create textual stability and constitute a reading (and translated) version. On the other hand, the suturing process accepts the instability of the work (ellipsis, variants, alternatives, erasures, interpretative disagreements etc.) and provokes the translator to search for an always elusive subject (or meaning) that flickers in the discursive chain and is unattainable by its own nature. Moreover, if the stitching process takes into account the context and the co-text of a poem in order to (re)construct meaning from the manifest content of the work, suturing operates at the level of its latent content, considering that the ellipsis, alternatives, variants, suppressions etc. create a regime of indeterminacy that the translator should accept and play with. Therefore, the translator's task is to work both under aesthetic and ethical constraints, since his choices are made before the transfer of the original to his own language. In order to illustrate this, we also present here the translation of Dickinson's fascicle 34 (1863), according to Cristanne Miller's Emily Dickinson's Poems: As She Preserved Them.

Keywords: Translation; Suture; Emily Dickinson.

\section{REFERÊNCIAS}

BERVIN, Jen; WERNER, Marta. The Gorgeous Nothings. Emily Dickinson's Envelope Poems. Edited by Jen Bervin e Marta Werner. New York/Paris: New Directions, 2013. CAMERON, Sharon. Choosing not Choosing: Dickinson's Fascicles. Chicago/ Londres: University of Chicago Press, 1992.

CARDOZO, Maurício Mendonça. Espaço versus prática da crítica de tradução literária no Brasil. Cadernos de Tradução, v. 1, n. 19, 2007, pp. 205-234.

DE MAN, Paul. Blindness and Insight. Essays in the Rhetoric of Contemporary Criticism. Minneapolis: University of Minnesota Press, 1983.

DERRIDA, Jacques. Des Tours de Babel. In: Psyché: Inventions de l'autre. Paris: Galilée, 1987, pp. 203-235. 
DERRIDA, Jacques. Signéponge. Paris: Editions du Seuil, 1988. (Col. Fiction et Cie.)

DICKINSON, Emily. Emily Dickinson's Poems: As she Preserved them. Edited by Cristanne Miller. Cambridge/Londres: Belknapp/Harvard University Press, 2016.

HART, Ellen Louise; SMITH, Martha Nell (orgs.). Open Me Carefully: Emily Dickinson's Intimate Correspondence to Susan Huntington Dickinson. Ashfield, MA: Paris Press, 1988.

LOSSO, Eduardo Guerrero. Prefácio. In: BINGEMER, Maria Clara; PINHEIRO, Marcus Reis (orgs.). Narrativas místicas: antologia de textos místicos da história do cristianismo. São Paulo: Paulus, 2016, pp. 9-26.

MILLER, Jacques-Allain. La suture (elements de la logique du signifiant). Cahiers pour l'Analyse, v. 1, n. 1, 1966, pp. 37-49.

MILLER, Cristanne. Emily Dickinson: A Poet's Grammar. Cambridge/Londres: Harvard University Press, 1987.

MILLER, Cristanne. Reading in Time: Emily Dickinson in the Nineteenth Century. Amherst/ Boston: University of Massachussets Press, 2012.

MÜLLER. A imagem poética: entre o material e o imaterial. Raído, n. 11, 2017, pp. 33-40.

OUDART, Jean-Pierre. Cinema and Suture. Screen, v. 18, n. 4, 1987, pp. 34-47.

SPIVAK, Gayatri Chakravorty. The Politics of Translation. In: VENUTI, Lawrence. The Translation Studies Reader. Londres/Nova York: Routledge, 200o, pp. 397-416.

VALÉRY, Paul. Cantiques spirituels. Varieté. Oeuvres complètes. V. 1. Paris: Gallimard, 1957, pp. 445-457. (Pléiade)

WERNER, Marta. Emily Dickinson's Open Folios: Scenes of Reading, Surfaces of Writing. Ann Arbor: University of Michigan Press, 1998. 


\section{[ANEXO]}

FASCÍCULO TRINTA E QUATRO

FOLHA UM aprox. final de 1863

O Luto que a gente sente

Por quem nunca vimos antes -

Mostra entre a nossa Alma e a deles

Laço Vital de Parentesco -

Pois Estranho - não chora Estranhos -

Quem sabe há amigos Imortais

Que a Morte antevê - saber disso

Nos paralisa ainda mais -

Que - tão vitais para Nós-

Quando levam sua Presença

Morrendo - É como se Nossa alma

[nosso] Mundo -. Nós mesmos - Sol

Ficasse de repente - Absconsa -

Bereavement in their death to feel

Whom We have never seen -

A Vital Kinsmanship import

Our Soul and theirs between -

For Stranger - Strangers do not mourn -

There be Immortal friends

Whom Death see first - 'tis news of this

That paralyze Ourselves -

Who - vital only to Our Thought -

Such Presence bear away

In dying - 'tis as if Our souls

Absconded - suddenly -

[Our] World -. Selves -. Sun -

Acho que Viver - deve ser um Êxtase

[ser] uma Vida

Para os que ousam tentar -

[que] tem permissão para

Além do meu alcance - conceber -

E do meu lábio - demonstrar -

Acho que meu coração usado

Podia alargar-se - até que

O Outro fosse a Margem

Pequenina - para o Mar - 
Acho que os Dias - podiam

Um por um ficar em Ordem -

E Majestade - ser mais fácil

Do que vida de pajem -

Sem súbito alarme - só a Diferença -

Sem Duende - na Flor -

Sem estalo no Ouvido da Apreensão -

Sem Falência - sem Danação -

[sem] clique

[Sem] Sepulcro -. Ermo

Mas Certezas de Sol -

Quente Verão - na Mente -

[de] Tarde

Meridiano [na]

Um Sul perene - na Alma -

Seu tempo Polar - aquém -

noite [Polar]

A Visão - bem ponderada -

Torna-se tão plausível

Que creio ser a ficção - real -

[tão] tangível -. positiva pareee

E o Real - parece fictício -

Que generoso, o Sonho -

Que Completo - ia ser

Se Minha Vida não tivesse sido um grande

Erro - Retificado - em Você

[sido] um. [sido] mero

[Erro]- qualificado - por

I think To Live - may be a Bliss

[a] Life

To those who dare to try -

[those] allowed

Beyond my limit - to conceive -

My lip - to testify -

I think the Heart I former wore

Could widen - till to me

The Other, like the little Bank

Appear - unto the Sea -

I think the Days - could every one

In Ordination stand -

And Majesty - be easier -

Than an inferior kind -

No numb alarm - lest Difference come -

[No] click

No Goblin - on the Bloom -

No start in Apprehension's Ear,

No Bankruptcy - no Doom -

[No] Sepulchre -. Wilderness

But Certainties of Sun -

[of] Noon

Midsummer - in the Mind -

Meridian [in]

A steadfast South - opon the Soul -

Her Polar time - behind - 
The Vision - pondered long -

So plausible becomes

That I esteem the fiction - real -

The Real - fictitious seems -

How bountiful the Dream -

What Plenty - it would be

Had all my Life but been Mistake

Just rectified - in Thee

Uma estradinha - que Homem não fez -

Ao Olho, aberta -

Acessível ao Eixo da Abelha -

E à Carroça da Borboleta -

Se há Vila - ao fim dela -

Não sei - se importa -

Só sei que - lá nenhum Tílburi

Me suporta -

A little Road - not made of Man -

Enabled of the Eye -

Accessible to Thill of Bee -

Or Cart of Butterfly -

If Town it have - beyond itself-

'Tis that - I cannot say -

I only know - no Curricle that rumble there

Bear me -
[So] tangible -. Positive appears

[fiction -] true

[The] Truth

[Life] been one. [been] bleak

[Just] qualified -
[Vila -] além

[Só] vejo - [não há um] Veículo [Me] leva [have -] besides

[only] sigh - [no] Vehicle hold - [me- $]$

\section{FOLHA DOIS c. final de 1863}

Sua Alegre vez de deixar a Herdade

Veio por Caminho Escuro -

Carruagens - Certo - Convidados - Também -

[Convidados - ] é verdade

Mas para Dia Festivo

Era Esforço mais penoso

Que faz o Mar Bem Cheio

Tentando saltar sobre Os Caracóis

[Tentando] dilatar

Que Ele lançou ao vento -

Nunca teve Noiva tal Corte -

Nunca cavaleiro de joelhos

Para saudar tão bela Fronte -

Bem lhe caiu a Grinalda - 
Passo mais justo - o Dela, à frente -

Que qualquer Borda

Arte de Neve - Truque de Lírio -

Possivelmente outorga -

Quem Quer que a peça - lá

No alto há de buscar o Pai

Como a Palmeira - no Deserto -

Busca obter o Céu -

A Distância - o único Gesto Dela -

Se é um Não - se é um Sim -

Concordância - ou Impedimento -

Quem quiser que adivinhe -

Esse - passe a Esquina de Cristal

Que obscurece seu Riso -

Esse - também deverá atingir

Igual Paraíso -

Her Sweet turn to leave the Homestead

Came the Darker Way -

Carriages - Be Sure - and Guests - True -

But for Holiday

'Twas more pitiful Endeavor

Than did Loaded Sea

O'er the Curls attempt to caper

It had cast away -

Never Bride had such Assembling -

Never kinsmen kneeled

To salute so fair a Forehead -

Garland be indeed -

Fitter Feet - of Her before us -

Than whatever Brow

Art of Snow - or Trick of Lily

Possibly bestow

Of Her Father - Whoso ask Her -

He shall seek as high

As the Palm - that serve the Desert -

To obtain the sky -

Distance - be Her only Motion -

If 'tis Nay - or Yes -

Acquiescence - or Demurral -

Whosoever guess -
Mais justo o passo [à frente]
Alguma vez [outorga]
[Quem quer que a] reclame

[único] Sinal

[passe primeiro] o limite

[Que] divide

[Guests -] too

[did] swelling

fitter for the feet [before]

Ever could endow -

[Whoso] claim

[only] Signal 
He - must pass the Crystal Angle That obscure Her face He - must have achieved in person Equal Paradise -

A Dor - tem um Traço de Branco Não se recorda quando

Começou - Ou se houve

Um Tempo em que não era -

Não tem Futuro - só a si -

Seu Infinito é portador

Do Passado - vislumbrando

Novos Períodos - de Dor.

Pain - has an Element of Blank It cannot recollect

When it begun - Or if there were

A Time when it was not -

It has no Future - but itself -

Its Infinite contain

It's Past - enlightened to perceive

New Periods - Of Pain.

\section{Tanto Verão}

Para mostrar

Ilegítima -

Ceder o mínimo Sorriso

Muito Exorbitante

Para a Dama

Com o Guinéu

Veja - se ela deve saber

Migalha Minha

Seria o bastante pra encher

O Armário do Tordo -

So much Summer

Me for showing

Illegitimate -

Would a Smile's minute bestowing

Too exorbitant first [must pass the Crystal] limit [That] divide
[A] Day -

[Muito] Extravagante -. Importuno -

[Com] os Guinéus

Poderia ser [o bastante]

[Too] extravagant -. Importunate - 
To the Lady

With the Guinea

Look - if she should know

Crumb of Mine

A Robin's Larder

Would suffice to stow -

FOLHA TRÊS c. final de 1863

Prometa-me Isto - Ao Morrer -

Que Me chamem logo -

Quero o teu último Suspiro -

A Mim cabe - Selar Teu Olho -

Não com Moedas - ainda que Cunhadas

Por Mão de Imperador -

Mas com meus Lábios - o único Fecho

Que teus Olhos baixos - pedem -

A Mim cabe ficar - quando partirem

Todos - Verificar

Se a Vida a mais rendida -

Vida Minha - restauro -

Derramo - Minha toda Libação -

Que Você veja só isso

Êxtase de Morte - Êxtase de Vida

Que se exalta - igual Você -

Devo - guardar O Pequeno Recinto -

Pedir ao Sol

Mais Orvalhos na Aurora

Ficando mais ao Sul

Pedir por Você um favor -

Que a Grama Enciumada

Não fique mais verde - ou mais amante

Para outra face amada -

E pedir à Nossa Senhora -

Se é que há Nossa Senhora

Que olhe por essa Criatura -

Que Cristo - Me - levou embora -

Só quero seguir Seu semblante -

Nunca tão afastada -

Por Meu Céu -
[Olhos] humildes

[Guinea]s

Could - [suffice]

[Que] alguém me chame

[minha] melhor [mais] tarde

\author{
provocar -. Persuadir [O Sol] \\ Novos -. Mais frescos [Orvalhos] \\ Tardando
}


Se eu não fosse

Ainda mais - recusada?
De todas as Suas Glórias -

Mais Amplamente -. Melhor seria ganhar -

versos 15-16: [Êxtase de Morte - Êxtase de Vida] ultrapassa/ mais Te assemelha

Extase de Morte - Êxtase de vida excede em/ Mais se Te parece -

Verso 27: [Que possa] olhar [por] tão pequena-. Sem graça [Criatura -]

Que possa olhar tão mera Criatura -

Promise This - When You be Dying -

Some shall summon Me -

[Some one] summon

Mine belong Your latest Sighing -

Mine - to Belt Your Eye -

Not with Coins - though they be Minted

From An Emperor's Hand -

Be my lips - the only Buckle

Your low Eyes - demand -

[Your] meek -

Mine to stay - when all have wandered -

To devise once more

If the Life be too surrendered -

Life of Mine - restore -

Poured like this - My Whole Libation -

Just that You should see

[My] best

Bliss of Death - Life's Bliss extol thro'

Imitating You -

Mine - to guard Your Narrow Precinct -

To seduce the Sun

Longest on Your South, to linger,

[To] entice -. persuade

Largest Dews of Morn

latest [on]

newest -. Freshest [Dews]

To demand, in Your low favor -

Lest the Jealous Grass

Greener lean - Or fonder cluster

Round some other face -

[Or] later linger

Mine to supplicate Madonna -

If Madonna be

Could behold so far a Creature -

Christ - omitted - Me -

Just to follow Your dear feature -

still [to]

Ne'er so far behind -

For My Heaven -

Had I not been

Most enough - denied? 
Remate de Males, Campinas-SP, v.38, n.2, pp. 581-619, jul./dez. 2018 - 611

Lines 15-16: [Bliss of Death - Life's Bliss] surpass in/ more ressembling You Bliss of Death - Life's Bliss excel in / More ressembling You

Line 27: [Could] regard [so] small -. Dim [a Creature -]

Could regard so scarce a Creature

Não tive tempo pra Ódio -

Porque

A Cova seria um entrave -

E a vida não era tão

Ampla que Eu pudesse

Acabar - a Inimizade -

Nem tive tempo pra Amor -

Mas já que

É bom ser Esperta -

A miúda Faina do Amor -

Pensei

Para Mim é coisa certa -

I had no time to Hate -

Because

The Grave would hinder me -

And Life was not so

Ample I

Could finish - Enmity -

Nor had I time to Love -

But since

Some Industry must be -

The little Toil of Love -

I thought

Be large enough for Me -

Minha Vida era - Arma Carregada -

Pelos Cantos - até que um Dia

Veio o Dono - legítimo - e

Levou-me em sua companhia -

Agora corremos as Matas

[percorremos] as

Soberanas caçando a Corça -

Toda vez que por Ele falo

O Morro manda o recado -

E se rio, a luz cordial

Cintila ao longo do vale - 
É como se a Face do Vesúvio

Houvesse espargido seu gozo -

E quando ao Mestre dou abrigo -

E quando à Noite - acaba o Dia -

É melhor que haver dividido

A Almofada mais macia -

Do seu inimigo - ó raiva -

Esse há de ficar bem quieto

[ficar] mal

Se lhe deito um Olho Amarelo -

Ou dou trela ao meu Dedo -

Embora eu possa - viver muito -

Vida mais longa - Ele vai ter -

Pois meu poder é só o matar,

Sem - o poder de morrer - $\quad$ [Sem -] a arte

My Life had stood - a Loaded Gun -

In Corners - till a Day

The Owner passed - identified -

And carried Me away -

And now We roam in Sovreign Woods - $\quad$ [roam] the -

And now We hunt the Doe -

And every time I speak for Him

The Mountains straight reply -

And do I smile, such cordial light

Opon the Valley glow -

It is as a Vesuvian face

Had let it's pleasure through -

And when at Night - Our good Day done -

I guard My Master's Head -

'Tis better than the Eider - Duck's

Deep Pillow - to have shared -

low [Pillow]

To foe of His - I'm deadly foe -

None stir the second time-

[None] harm

On whom I lay a Yellow Eye -

Or an emphatic Thumb -

Though I than He - may longer live

He longer must - than I-

For I have but the power to kill,

Without - the power to die -

[the] art 
A Aurora vem para Ambos -

O Leste - guarda atrás do Morro

A Fidelidade Púrpura -

A Tarde desdobra o Azul

Até estender-se entre os Dois -

Maior - largura -

Nem há de a Noitinha esquecer

Para Cada Um - uma Lâmpada -

Mechas tão distantes -

O Norte - erige

O sinal Brilhante de Iodo -

Até que Ambos - enxergam -

Os Braços escuros da Noite

Juntam Hemisférios, e Casas

E assim

Em Seu Seio - Um -

E Outro em Sua Barra -

Deitam-se -

The Sunrise runs for Both -

The East - Her Purple Troth

Keeps with the Hill -

The Noon unwinds Her Blue

Till One Breadth cover Two -

Remotest - still -

Nor does the Night forget

A Lamp for Each - to set -

Wicks wide away -

The North - Her blazing Sign

Erects in Iodine -

Till Both - can see -

The Midnight's Dusky Arms

Clasp Hemispheres, and Homes

And so

Opon Her Bosom - One -

And One opon Her Hem -

Both lie -

O Triste-Pia - não inverte o Canto

Quando na única Árvore

Que ele pensava ocupar

Um Fazendeiro há - 
Agarra-se à Raiz -

O Espaçoso Futuro -

O Horizonte - foi Ótimo -

Bravo Triste-Pia - *

Cuja música é $\mathrm{O}$

Único Anódino -

No Bobolink - reverse His Singing

When the only Tree

Ever He minded occupying

By the Farmer be -

Clove to the Root -

His Spacious Future -

Best Horizon - gone -

Brave Bobolink -

Whose Music be His

Only Anodyne - ao Cerne

Todo [Horizonte] - conhecido

* No manuscrito, ED inverteu os versos finais, provavelmente ao copiar, mas numerou a ordem: 2 Whose Music be His/Only Anodyne -/1Brave Bobolink -

\section{FOLHA CINCO c. final de 1863}

Uma só Benção tive, e o resto

Tão grande para meus Olhos

Que parei de aferir - satisfeita -

Com medida de maravilhas -

Era o limite do meu Sonho -

O foco do meu Pensamento -

Um perfeito - paralisante Êxtase -

Contente Descontentamento -

Já não sentia Frio - Desejo -

Ambos se tornaram Fantasia

Pois o novo Valor na Alma

[se tornaram] Fictícios

Suprema Soma Terrena -

[nov]a Fortuna - . porção

O Céu de baixo o Céu de cima -

Obscuros de mais rubro Azul -

A Grandeza da Vida inclinou-se - total -

[de] mais próximo. gracioso

Finou-se - até - o Juízo Final -

Por que o Êxtase paga tão pouco -

Por que o Paraíso difere - séculos

[Êxtase tão] pouco - expressa. permite

Por que Nos servem Enchentes - em Taças -

[Paraíso] se nega

Isso já não especulo - 
One Blessing had I than the rest

So larger to my Eyes

That I stopped guaging - satisfied -

For this enchanted size -

It was the limit of my Dream -

The focus of my Prayer -

A perfect - paralyzing Bliss -

Contented as Despair -

I knew no more of Want - or Cold -

Phantasms both become

For this new Value in the Soul -

Supremest Earthly Sum -

The Heaven below the Heaven above -

Obscured with ruddier Blue -

Life's Latitudes leant over - full -

The Judgment perished - too -

Why Bliss so scantily disburse -

Why Paradise defer -

Why Floods be served to Us - in Bowls -

I speculate no more -

A Vitória chega tarde - *

E vale pouco a lábios frios -

Por demais absortos na geada

Para a receber -

Que doce seria o sabor -

Uma Gotinha -

Deus é econômico assim?

Para nós Sua Mesa é muito alta -

Só se jantarmos na Ponta Dos Pés -

Migalhas - para as boquinhas -

Cerejas - para o Tordo -

A Ceia das Águias - não é para seu bico -

Deus cumpra a Promessa aos Pardais -

Parcos de Amor - eles sabem a fome -

Victory comes late -

And is held low to freezing lips -

Too rapt with frost

To take it -

How sweet it would have tasted -

Just a Drop -

Was God so economical? fictitious [both]

[new] fortune -. portion -

[with] nearer. comelier

[so] cautiously-express -. afford [Paradise] demur - 
His Table's spread too high for Us -

Unless We dine on Tiptoe -

Crumbs - fit such little mouths -

Cherries - suit Robins -

The Eagle's Golden Breakfast strangles - Them -

God keep His Oath to Sparrows -

Who of little Love - know how to starve

* Enviado como carta a Samuel Bowles em 1861, retomado em 1863 no Fascículo 34. O tema dos pardais aparece em Mateus 10:29-31, e o tom do último verso evoca as bem-aventuranças do Sermão da Montanha (Mateus 5).

As Montanhas - crescem em segredo Erguem seus trajes de Púrpura

Sem esperar - Exaustão -

Aplauso - ou Público -

Em suas Faces Eternas

O Sol - só por deleite

Mais longo - dura - d'ouro -

Para acompanhar - a noite -

com largo [deleite]

[Para] simpatizar com -

The Mountains - grow unnoticed -

Their Purple figures rise

Without attempt - Exhaustion -

Assistance - or Applause -

In Their Eternal Faces

The Sun - with just delight

Looks long - and last - and golden -

[with] broad

For fellowship - at night -

[For] sympathy

Esses - viram Visões -

Tranca-os suavemente -

Amarra. Prende [os]

Esses - de Risos francos -

Fecha-os devagar -

Esta - fez versos de partida -

Ágil - Doce Boca - saudades de ti -

$\operatorname{logo}[-$ Doce $]$

Esta - saudamos -

Inumerável - Cetim -

Estes - tivemos conosco -

[Estes - afagamos]

Dedos da Esbelta Aurora -

Não tão arrogante - a Tarde -

Estes - justo - vieram a Nosso alcance - 
Pérola - para meia - Pérola para Sapato -

Paraíso - único Palácio

Que A recebe - agora -

These - saw Visions -

Latch them softly -

These - held Dimples -

Smooth them slow -

This - addressed departing accents -

Quick - Sweet Mouth - to miss thee so -

This - we stroked -

Unnumbered - Satin -

These - we held among our own -

Fingers of the Slim Aurora -

Not so arrogant - this Noon -

These - adjust - that ran to meet Us -

Pearl - for stocking - Pearl for Shoe -

Paradise - the only Palace

Fit for Her reception - now -

Goles do Seu Estimulante Espírito

Habilitam-me - ao Caminho

Do Deserto ou do Ermo

Como levasse selado Vinho -

Como Quem atinge - o traço

Do Camelo - tornar-se elástica -

Que poderoso o estímulo

De uma Mente Hermética -

Strong Draughts of Their Refreshing Minds

To drink - enables Mine

Through Desert or the Wilderness

As bore it sealed Wine -

To go elastic - Or as One

The Camel's trait - attained -

How powerful the stimulus

Of an Hermetic Mind -
[Pérola -] a [meia- Pérola -]

o sapato -

bind. Bar [them]

soon [Sweet]

[Pearl-] the-[stoking-Pearl]thePearl]the-

Ela nos faz falta, não porque Vemos - *

A Ausência de um Olho -

[A] Viagem

Salvo se sua Mente acompanha -

Abrevia a Companhia

Condena. proíbe -. priva [a 
Tão breve como Estradas de Estrelas -

Nós - deitadas no chão -

Sabemos que Os Seus Olhos Superiores

Nos incluem - quando se vão -

We miss Her - not because We see -

The Absence of an Eye -

Except its Mind accompany -

Abridge Society

As slightly as the Routes of Stars -

Ourselves - asleep below -

We know that their superior Eyes

Include Us - as they go -
Companhia]

[como] os voos

Vêm melhor -. Nos levam

[The] Journey

impair. debar -. deprive [Society]

[As] scarcely [as the] flights

Scan better -. Convey Us - [as]

* Enviado a Susan G. Dickinson (1863), variante.

Óleos Essenciais - se extraem - *

O Aroma de Rosas

Não o expressa só - o Sol -

É Presente de Prensas -

A Rosa Geral - decai -

Mas esta - da Gaveta íntima

Faz Verão - se a Moça jaz

Em Perene Alecrim -

Essential Oils - are wrung -

The Attar from the Rose

Be not expressed by Suns - alone -

It is the gift of Screws -

The General Rose - decay -

But this - in Lady's Drawer

Make Summer - When the Lady lie

In Ceaseless Rosemary -

*Enviado a SD (1863). Provável referência aos versos de Josiah Holland, editor do Springfield Republican: "Corações são como maçãs, duros e amargos/ Até serem amassados pela dor e seu poder irresistível/ E darem seus sucos ricos e brandos/ Para a mão pesada do desespero" (Bitter-Sweet, 1858); e também a Keats, "Ode à Melancolia”. Cf. Hamlet, IV, 5: "There's rosemary, that's for remembrance. Pray you, love, remember. And there is pansies, that's for thoughts." A versão enviada a SD terminava com "In Spiceless Sepulchre" [em Sepulcro sem Aroma]. "Drawer" pode ser gaveta, mas também roupa íntima. Os 40 fascículos de ED foram encontrados na gaveta de sua pequena escrivaninha. 
Correspondência dos poemas do Fascículo 34 com as edições de Franklin e Johnson:

Bereavement in their death to feel [F756A; J645]

I think To Live - may be a Bliss [F757A; J646]

A little road - not made of Man - [F758A; J647]

Her Sweet turn to leave the Homestead [F759A; J649]

Pain - has an Element of Blank - [F76oA; J65o]

So much Summer [F761A; J651]

Promise This - When You be Dying - [F762A; J648]

I had no time to Hate - [F763A; J478]

My Life had stood - a Loaded Gun - [F764A; J754]

The Sunrise runs for Both [F765A; J710]

No Bobolink - reverse His Singing [F766; J755]

One Blessing had I than the rest [F767A; J756]

Victory comes late - [F191B; J695]

The Mountains - grow unnoticed - [F768A; J757]

These - saw Visions - [F769A; J758]

Strong Draught of Their Refreshing Minds - [F770A; J711]

We miss Her, not because we See - [F771A; J993]

Essential Oils - are wrung - [F772A; J675] 